\title{
EFFECT STUDENT AND TEACHER RESPONSE TO THE USE OF INTERACTIVE MULTIMEDIA IN THE LEARNING PROCESS
}

\author{
Silfia Andini, Aulia Fitrul Hadi \\ ${ }^{1,2}$ Universitas Putra Indonesia YPTK Padang \\ email: silfia_andini@upiyptk.ac.id
}

\begin{abstract}
This study aims to analyze how the response of class XI students and the response of the teacher at SMK PERBANKAN Padang to the use of Interactive Multimedia in the learning process. There were 150 students and 8 teachers at the school who were the research samples. In this study, there are two problems investigated, namely how students respond to the use of Interactive Multimedia in the learning process of learning and how the teacher responds to the use of Interactive Multimedia in the learning process of learning. The data obtained in this study were in the form of student response questionnaire data and teacher response questionnaire data. The data were analyzed using descriptive analytical methods to obtain answers to the problems in the study. Based on the results of the study, it was found that $88 \%$ of students responded positively to the use of interactive multimedia in the learning process of mathematics. And as many as $75 \%$ of teachers responded positively to the use of interactive multimedia in the learning process because learning activities carried out using interactive multimedia were more active and felt fun for students and teachers..
\end{abstract}

Keywords: Elearning, Multimedia, Blended Learning

\section{INTRODUCTION}

In order to improve national development, teachers act as the vanguard in order to produce quality human resources. In connection with this in the learning process of this century there are two challenges that must be faced by teachers, the first challenge comes from a change in perceptions about learning itself and the second challenge comes from the existence of information and telecommunications technology which shows extraordinary developments so that this century is known as technological century [1]. To face these challenges, teachers need the help of learning media as a delivery / channel of information in the learning process in order to maximize learning objectives. Learning media have a contribution in improving the quality and quality of learning. The presence of instructional media not only helps teachers in delivering their teaching materials, but also provides added value to learning activities. This applies to all types of media, both sophisticated and expensive, or simple and inexpensive learning media. In connection with technological developments, the existing learning media have also developed. Many media are developed using the help of technology. One of the growing media is known as multimedia. According to Munadi [3] "Multimedia learning is a medium that can involve many senses and organs during the learning process". Arsyad [4] argues that "multimedia can be a combination of text, graphics, animation, sound and video". Smaldino et al. [5] stated that: "Multimedia systems may consist of traditional media in combination or they may be in-corporate the computer as a display device for text, pictures, graphics, sound, and video. The term multimedia goes back to the 1950s and describes early attempts to combine various still and motion media for heightened educational effects. Interactive multimedia is a technology application in learning. The emergence of multimedia development in learning cannot be separated from learning theory and other theories that 
support it. According to Thompson \& Simonson [6] there are three learning theories that support the use of computers I multimedia in learning. The three theories are theoretical language theory, systems theory, and cognitive theory. Heinich [7] argues that the use of media and technology in learning is based on behavioristic theory, cognitive theory, constructivism theory, and social learning theory. The use of interactive multimedia in the learning process is a demand for 21 st century learning, this is due to the increasingly rapid development of information technology which requires the world of education to always adapt [8]. teachers are required to be able to create integrated creative and innovative learning. In the framework of 21 st century competence, it is explained that knowledge through core subjects is not enough, it must be equipped with creative, critical, strong character abilities (responsible, social, tolerant, productive, adaptive), besides that it is supported by the ability to utilize information and communication with the indicator being information literacy, media literate, and ICT literate [8]. From the government side, Indonesia is committed to making changes related to the use of technology in education. One of the most striking updates is the introduction of ICT subjects starting at the elementary level in 2004. This application aims to prepare students to be involved in rapid changes in the development of information technology [9]. This step is further strengthened by the plan to implement the 2013 Curriculum where ICT subjects will be integrated into all subjects [10]. This means that every teacher must be able to operate ICT and optimize ICT as a medium / means that can enrich teaching materials. Related to that, the National Education Standards Agency (BSNP) as published in the National Education
Paradigm in the 21st Century, argues, the educational paradigm that is democratic, nuanced of play, full of openness, challenges, trains a sense of responsibility, will stimulate students to come to school or to campus because they are happy, not because they are forced to [11]. By taking the basis of Permendiknas Number 16 of 2007 concerning Academic Qualification Standards and Teacher Competencies which are one of the Standards for Teachers and Education Personnel. The standard contains a list of pedagogical, personal, professional and social competencies that are integrated into teacher performance.

\section{METHOD}

The research conducted is descriptive research, namely research that aims to describe an independent variable, either only one or more variables. So the researcher does not make comparisons of these variables in other samples, or look for relationships between variables. The study was conducted to determine how teachers and students responded to the use of interactive multimedia in the mathematics learning process. The research was conducted in Class XI SMK PERBANKAN PADANG with a research sample of 125 students of class XI SMK PERBANKAN PADANG in the academic year 2019. The data analyzed were student response questionnaires and teacher response questionnaires. After the data is collected, data processing is carried out. Then analyzed descriptive analytical data to answer the research questions.

\section{RESULT}

The data obtained in this study came from the answer sheet for teacher response questionnaires and student response questionnaires to the use of multimedia in the learning process. The two questionnaires were arranged based on predetermined indicators. The teacher response questionnaire indicators 
are as follows: 1) Media can overcome the limitations of experience that students have 2) Media can overcome classroom boundaries 3) Media can allow direct interaction between participants and their environment 4) Media can add basic concepts that are true, real and precise 5) Media can control students' learning speed 6) Media can provide a comprehensive experience from concrete to abstract things While student response aspects are arranged with the following indicators: 1) Content Quality Aspects 2) Pleasure Aspects 3) Evaluation Aspects 4) Grammar Aspects 5) Usage Aspects Illustration: The research results show that for the teacher response questionnaire as much as $78 \%$ of the teachers gave a positive response to the media indicators that could overcome the limitations of experience that students had, $74 \%$ gave positive responses to the indicators that the media could overcome the boundaries of the classroom. $76 \%$ of teachers gave positive responses to indicators that media could allow direct interaction between participants and their environment, as many as $72 \%$ of teachers gave positive responses to indicators that media can add basic concepts that are true, real and precise, as many as $75 \%$ of teachers give positive responses to indicators media can control the speed of student learning. And as many as $75 \%$ of teachers gave positive responses to indicators. Media can provide a comprehensive experience from concrete to abstract things. It can be concluded that the overall measured aspects of $75 \%$ of teachers gave positive responses to the use of multimedia as a medium in the mathematics learning process. For the student response questionnaire as many as $84 \%$ of students responded positively to the Multimedia Quality Aspects indicator, As many as $90 \%$ of students gave a positive response to the Pleasure Aspect indicator towards the use of multimedia in the mathematics learning process, as many as $89 \%$ of students gave a positive response to the Evaluation Aspect indicators contained in multimedia, and as many as $89 \%$ of students gave positive responses to the Grammar Aspect indicators, and as many as $89 \% .88 \%$ of students gave a positive response to the indicators of the aspect of using illustrations contained in the multimedia used in the learning process. Overall, the positive responses given by students to learning using multimedia were $88 \%$. The results of the study are summarized in Table 1

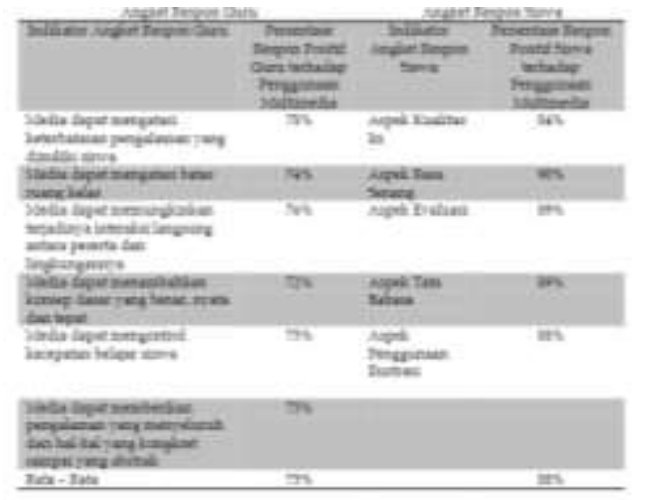

.Table 1. Percentage of Teacher Response

Questionnaire and Student Response Questionnaire

From the research results, when viewed from the side of the teacher and student responses, it is known that both teachers and students really appreciate and are very happy with learning carried out using multimedia assistance. This is known from the positive responses they give to each indicator contained in the questionnaire provided. However, if examined more deeply, the positive responses they give are not directly proportional to other supporting factors. They strongly support the demands given by the government and 21st Century Skills to implement technology-based learning, but despite the fact that what is happening in the field of demand cannot be fully implemented properly and maximally by teachers. During the research, several factors were found which 
hindered the implementation of the use of multimedia in the learning process of mathematics in schools as follows:

Lack of availability of facilities and infrastructure to support the use of multimedia, such as computers, electricity, and classrooms. 2) Lack of teacher's ability to develop interactive multimedia 3) Lack of availability of interactive multimedia that is suitable for the topic to be studied. 4) Lack of training for teachers from the government concerned the use of multimedia in the learning process 5) The lack of time available for the teacher to develop the appropriate multimedia by themselves 6) The lack of the teacher's ability to develop and utilize multimedia in the learning process. 7) There are too many demands for learning objectives to be achieved. So that most teachers only focus on achieving learning targets. Students unprepared to learn to use multimedia assistance

These constraints are a scourge in itself for teachers, and interfere with the readiness of teachers to apply learning using interactive multimedia. The results and findings of this study are consistent with the results of research conducted by several researchers in developing countries. When compared with similar research in several developing countries such as research conducted by Hassand al., States that the use of ICT (multimedia) in learning increases student interest in learning material and provides

better learning outcomes than previous learning [14], further research conducted by Khan provides The finding that the introduction of ICT in the learning process in developing countries like Bangladesh is very enthusiastically welcomed by educational actors such as teachers, parents and students. It's just that there are still obstacles in its application such as lack of facilities and infrastructure as well as skills from the human resources possessed.

\section{CONCLUTION}

Based on the research results, the percentage of teacher responses to the use of interactive multimedia in the mathematics learning process is $75 \%$. If assessed from each indicator $78 \%$ of teachers give positive responses to indicators that media can overcome the limitations of experiences that students have, $74 \%$ give positive responses to indicators that media can overcome class room boundaries, as many as $76 \%$ of teachers give positive responses to indicators that media can enable the occurrence of direct interaction between participants and their environment, as many as $72 \%$ of teachers gave positive responses to media indicators that could add basic concepts that were true, real and precise, as many as $75 \%$ of teachers gave positive responses to indicators that media could control student learning speed. And as many as $75 \%$ of teachers gave positive responses to indicators. Media can provide a comprehensive experience from concrete to abstract things. For the student response questionnaire as much as $84 \%$ of students gave a positive response to the Multimedia Quality Aspect indicator, as many as $90 \%$ of the students gave a positive response to the Pleasure Aspect indicator of the use of multimedia in the mathematics learning process, as many as $89 \%$ of students gave a positive response to the Evaluation Aspect indicators contained in multimedia, and as many as $89 \%$ of students gave a positive response to the indicators of the Grammar Aspects, and as many as $88 \%$ of students gave positive responses to the indicators of the Aspects of Using Illustrations contained in the multimedia used in the learning process. Overall, the positive response given by students to learning using multimedia was $88 \%$. Based on the results of these 
percentages, when viewed from the side of teacher and student responses, it is known that both teachers and students really appreciate and are very happy with learning carried out using multimedia assistance.

\section{REFERENCE}

[1] Osman, K., \& Lee, T. T. (2014). IMPACT OF INTERACTIVE MULTIMEDIA MODULE WITH PEDAGOGICAL AGENTS ON STUDENTS'UNDERSTANDING AND MOTIVATION IN THE LEARNING OF

ELECTROCHEMISTRY. International Journal of Science and Mathematics Education, 12(2), 395-421.

[2] Harefa, N., Tafonao, G. S., \& Hidar, S. (2020). Analisis Minat Belajar Kimia Siswa Melalui Pembelajaran Berbasis Multimedia. Paedagoria: Jurnal Kajian, Penelitian dan Pengembangan Kependidikan, 11(2), 81-86.

[3] Harefa, N., Tafonao, G. S., \& Hidar, S. (2020). Analisis Minat Belajar Kimia Siswa Melalui Pembelajaran Berbasis Multimedia. Paedagoria: Jurnal Kajian, Penelitian dan Pengembangan Kependidikan, 11(2), 81-86.

[4] Effendi, D. (2014). Learning Application Using Multimedia For 5th Graders Elementary School Student about "Photosynthesis in Plants". In Proceding The 1stSriwijaya University Learning and Education International Conference (SULE-IC), ISBN (pp. 987-602).

[5] Yustiqvar, M., Hadisaputra, S., \& Gunawan, G. (2019). Analisis penguasaan konsep siswa yang belajar kimia menggunakan multimedia interaktif berbasis green chemistry. Jurnal Pijar Mipa, 14(3), 135-140.

[6] Adri, M. (2007). Strategi Pengembangan Multimedia Instructional Design. Jurnal Invotek, 8(1), 1-9

[7] Aninda, M. I. (2015). The Use Of Multimedia In Teaching Vocabulary To The First Grade Students At Smp
Muhammadiyah 7 Surakarta In 2014/2015 Academic Year(Doctoral dissertation, UNIVERSITAS MUHAMMADIYAH SURAKARTA).

[8] Sriadhi, S., Gultom, S., Restu, R., \& Simarmata, J. (2018, July). The effect of tutorial multimedia on the transformator learning outcomes based on the students' visual ability. In IOP Conference Series: Materials Science and Engineering (Vol. 384, No. 1, p. 012059). IOP Publishing.

[9] Khoiriah, K., Jalmo, T., \& Abdurrahman, A. (2016). The Effect of Multimedia-based Teaching Materials in Science Toward Students' Cognitive Improvement. Jurnal Pendidikan IPA Indonesia, 5(1), 75-82.

[10] Nulhakim, L., Setiawan, F. R., \& Saefullah, A. (2020). Improving Students' Creative Thinking Skills Using Problem-Based Learning (PBL) Models Assisted by Interactive Multimedia. Jurnal Penelitian \& Pengembangan Pendidikan Fisika, 6(1), 916.

\section{THANKS}

Thanks to Universitas Putra Indonesia YPTK Padang for supporting and providing research funding so that we can publish this article. 